\title{
COLOUR IN THE CITY: PRINCIPLES OF NATURE-CLIMATE CHARACTERISTICS *
}

UDC 711.4.01:72.017:551.58=111

\section{Dragana Vasiljević Tomić}

\author{
Faculty of Architecture, University of Belgrade, Serbia \\ *draganavt@arh.bg.ac.rs
}

\begin{abstract}
The phenomenon of colour is examined through the evolution of colour and development of culture of colour, principles of nature-climate characteristics which significantly affects the colouristic priorities of people and the colour of the city itself. The terms functional colour and climate of colour are also considered, as some of the most important characteristics of architectural and urban design practice. The role of the urban public space in functioning of the city is defined through the essential characteristics of urban public space, which are cultural identity, nature, climate characteristics physical structure and its function. The complexity of colouristic attributes of the urban public space is conditioned by the basic characteristics: colouristic priorities, harmony of coloured spatial structures and materials in designing the polychrome ambient in the city. The factors that shape the colouristic ambient of the city are: characteristics of nature and climate, interrelations of colour and shape, as well as the experience of the form of the urban public space while preserving its identity. Upon the newly formed principles, the transformed model of the urban public space as a polychrome ambient is built.
\end{abstract}

Key words: colour, polychrome, culture, nature-climate characteristics, space.

\section{INTRODUCTION}

The vitality of a city - a relation between space and its function - can lie within its historicalness, exoticness, colourfulness and extraordinariness of spaces, architecture, customs, climate characteristics, city rhythm and culture. The widest range of urban activities, dynamic authenticity, functional organisational openness and availability are the main criteria set for the polychromatic public space and its contents. Spaces that are to be brought to life, built, and then used through the process of animation, are analysed. The aesthetic attributes of a space can be used for citizens' animation purposes only [1].

\footnotetext{
Received

* Acknowledgement: The article was written as a part of science research project - Spatial, energetic and social aspects of settlements' development and climate changes, NIP 36035
} 


\section{Appearances AND Boundaries of the CUlture of Colour}

The phenomenon of colour is characterized by the system of sustainable and associatively new semantic meanings. It is objectively determined but still open for improvement towards every individual; this enables its dynamic development within social culture. The phenomenon of colour that carries semantic, emotional and aesthetic information is called the culture of colour. It originated and continues to exist in a variety of social-spatial processes and represents a specific reflection of the spiritual condition and the level of material-spatial environment of the society, groups and individuals.

Within different cultures an association between colour and objects, occurrences and conceptions evolved, leading towards crystallization of the system of colouristic symbols, which significantly outlast time-frame of a single generation. A man used colour based on his life-experience: in the context of his natural, material surroundings, way of life while concurrently relying on symbolism of colour - the collective experience of the past generations. For instance, red colour expressed love, joy, upcoming danger; blue correlated with images of big distance, knowledge, wisdom. A wide range of different ideas is connected to the same colour.

The boundaries of the culture of colour define the epoch and geographic frame in which it exists. We can distinguish the influence of the regional centres where the colour canons emerge and disappear and colour traditions mature, with the tendency to expand beyond the borders of its geographical boundaries. [2] The factors influencing the creation and expansion of the culture of colour can be divided in natural-climatic (natural components and various urban elements is also noticeable: the land morphology, water surfaces, vegetation, microclimate on one hand and urban structure and built city core on the other), psychological and historic-cultural. The elements of culture of colour are colour manifestations in objects of the material world that reflect the symbolism of colour and philosophical idea of colour.

Could an assumption be made that the phenomenon of the culture of colour develops as a result of emerging and disappearing of colour canons? The canon is born in art and then transposed through free associations into everyday life. This is how the tradition of colour is created with its active core - colour canon. Simultaneously, the process of decanonization takes place on account of occurrence of new associations depending on the social-cultural correlation. The breakdown of a canon leads to the collapse of one tradition of colour and birth of another. The status and level of the culture of colour is defined by the system of traditions of colour, their specific characteristics, connection to the general spiritual and material culture of the a nation, social group or a person. The degree of culture of colour in a region in a certain segment of time depends on the general level of culture, that is, exactly, what enables a complete evolution of colour symbolism and associative colour thinking, and also forms tendencies regarding colour priorities. [3]

Besides, considering the tendency to intensify the interaction among diverse cultures of colour, one could say that the colour acquirement became a general good; sparkling colours of Karnack temples, Pompeian house paintings, Byzantine mosaics, Gothic cathedral stained glass, Persian miniatures, Russian icons, Orthodox churches. The culture of colour inheritance - creative experience and scientific research results - is used in many countries for the purpose of colouristic creation of spatial surroundings. 
During last few decades, tendency to use colour as a form-creating instrument was increasingly present and it has been international phenomenon in culture of colour. Historical documentation survey, aesthetical and psychological approach generated their expression within architectural colour interpretation.

Architectural approach to organization of the professional tasks within this approach often ignores psychological and cultural components of architecture; for instance, infinitely repeated elements in multi-storey buildings made of large blocks are once again mechanically replicated in colour, emphasizing their form, which leads to monotony of majestic architectural masses highlighted by colour. It is obvious that colour design must consider improvement of the architectural quality of the space, aesthetic expression and pleasant psycho-climate, all according to the type of the social activity. This justifies ambient oriented approach in colour design of public urban spaces, which combines spatial and social demands. Such an approach can be achieved by relying on the overall legacy of the culture of colour.

\section{COLOUR PRIORITIES}

Colour priorities were initially formed in the area of conceptual colour, based on colour symbolism and aesthetics, and as such could be called ideal. Colour priorities exist exclusively in one's conscience and are significantly transformed once the material object - a colour bearer - is present. The same man never connects a certain colour spectrum to different objects, such as telephone, a suit, a car, or a building. Therefore, when speaking of colour priorities, the type colour bearing object is always specified. Thus, the colour priorities problem has always been in architects' attention. [4]

Numerous colour associations that had entered our lives way back in the prehistoric era and were transformed into secular symbolic systems, enable speaking of colour language that existed in ancient nations and was expressed in architectural polychrome. The archaic character of colour associations is confirmed by the fact that some of them are typical among very different civilizations, such as Chinese and European, or Ancient Egyptian and Ancient Greek. The history of art and linguistics asserts that essential colours in the primal human community were white, black and red. Exactly these colours were the first to be associated to a specific idea.

Polychrome and monochrome as representations of, respectfully, abundance and asceticism of colour were constantly replacing each other during human history. Polychrome was usually articulation of national principle whereas monochrome was an expression of a more "refined" relationship to colour of a certain part of the society. The sphere of emotional impression is closer to polychrome while the sphere of ratio connects to monochrome. Goethe, as the one who set the foundations for analysis of this phenomenon, states that educated people show quite an aversion towards colour. This can be a result of visual weakness or partly from unrefined taste that prefers being neutral.

The factors that affect forming of the coloured structures in public urban space are:

- Relation of the form and the colour of the public urban space

- Natural-climatic characteristics

- Perception of the public urban space form through cultural identity of the surroundings 
Each of the mentioned factors respects, in its own way, the specificities of the structure of architectural and urban form; together, they determine the creation of coloured structures in public urban space.

\section{Principles of NATURE - Climate Characteristics}

The formation and appearance of coloured structures in public urban space depends, above all, on natural ambient, the most extensive factor, with its direct and indirect obvious influence on urban fabric and culture of colour. The interaction among natural components and various urban elements is also noticeable: the land morphology, water surfaces, vegetation, microclimate on one hand and urban structure and built city core on the other.

The dynamics of colour ambient of the city descend because of the disturbance of the specific balance of natural elements by urbanisation expansion. The colouristic image of natural ambient depends upon numerous elements. Amongst those are: climate conditions, atmosphere composition, level of pollution and overheating degree; temperature oscillations causing fog, rain and snow; morphological specifics of the area, including land configuration; the relief structure of coloured surface influencing overall reflection; and, finally, the colour shade itself. The eroded soil without any vegetation upon it directly reflects on the polychrome of natural surroundings, or in case of the strong wind carrying dust and changing overall colour of the location. The existing flora significantly affects the chromatic elements of natural ambient.

All the components of natural surroundings are interconnected. Thus, for example, low temperatures extensively transform natural ambient: the colour of vegetation and soil is altered and frosted water surfaces are covered with snow. Wintertime is characterized by larger percentage of achromatic components in natural environment palette. [5]

The colour shades of natural ambient change depending on the direction and speed of the wind moving the vegetation and creating living structure, filling the air with flying particles. Of all the climate characteristics, the one causing the most powerful colour influence on the natural environment is sunlight. Its quality (spectrum) and quantity (during one day or by seasons) fulfil the colouristic appearance of the natural ambient.

However, the wide range of researches ignores the question of colour. The cultural and structural analysis of polychrome of ambience would significantly enrich its reach. The semantic and visual characteristics of the space, abstracted of colouristic data, cannot truthfully characterize the natural environment. The components of natural ambient without their colouristic expression do not represent authentic base for the research. These belong to the area defined as "psychological-aesthetical potentials of natural ambient", "surroundings' resources" and their "visual accessibility". The sustainability of general cultural potential of urban ambient is unreal without having colouristic importance of natural elements in city core in sight.

The natural ambient polychrome research done by French experts is considered the most important. The basic characteristic of the work of French colourists in the field of architecture and urbanism during last two decades, is considering the role of colour in the volume of the cities (even the regions); this produced the need of colour research in various spatial areas of the country. 
The most systematic studies were done by colourist Jean-Philippe Lenclos [6], who simultaneously analysed natural surroundings and results of human activity (historical, architectural) as homogeneous environment. In 1967, Lenclos started analysing the polychrome of several areas in France. During several years, he analysed Bretagne and the Loire valley, Normandy and Provence, Burgundy, Limousine and other provinces.

The method of Lenclos consists of three phases: spatial analysis, visual synthesis, and creation of "colour card", according to the location. This method was used in research of a variety of locations, rural and urban, and enabled analysis of natural ambient with respect to architectural objects and urban surroundings, in which the natural components are imbedded in architectural framework. This method treated nature and architecture as homogeneous system.

The first phase is the analysis of components that represent constants of colouristic characteristics (land, sand, pile of stones, rocks etc.) as well as components with clearly defined colour dynamics (sky and vegetation with changeable sun exposure). The first phase also includes analysis of samples of soil, walls, roofs and details of buildings, and vegetation elements. While gathering the information, Lenclos makes colour sketches, drawings and photographs of the location.

The main aim of the second phase is defining the general chromatic characteristics as a result of colour samples classification. Those general characteristics are used by Lenclos as a base for chromatic solutions for specific buildings that can be built in the analyzed area. The colour combinations within defined colour plurality enable acquiring series of varieties suiting the basic demand - chromatic interaction with the surroundings. Besides, gained data represent the statistic material for the usage of certain palette or colour combination on the location.

Finally, in the third phase the "colour card" is made - practical manual for application of colour. The "colour card" includes two palettes - general and specific, which mutually cooperate and guarantee the harmony of all the combinations based upon those. The general palette consists of calm, modest colours and is used for bigger areas (walls, roofs, pavements); specific palette includes strong, saturated colours and is used for details emphasis (doors, windows, plinths, cornice). Lenclos used his method not only in colour analysis of natural but also urban surroundings.

In the year 1970, Lenclos carried out the colour analysis of Tokyo downtown, upon the request of the Colour city planning centre. Chaotic urban development, combination of traditional and contemporary architecture formed a complex chromatic conglomerate incorporating natural and artificial materials, different in structure and texture. The city was divided in sectors, depending whether contemporary, traditional, industrial or combined architecture was prevailing in its spatial structure. Specific chromatic dominants were determined for each of the sectors. The results of the analysis became objective platform for dealing with functional and artistic aspects of colour application in city core and in creating building materials industry.

The continuous dynamic of polychrome in a city has a very important role in the colouristic urban environment: shop windows, traffic, pedestrians, billboards etc. that can be perceived on the ground level.

The French colourists F. and M. Klee [7] think that there is a certain colouristic interaction between natural environment and manmade surroundings. This reciprocal connection is to be found and understood in order to build urban polychrome system, a sort 
of "plasma" connecting visual elements of the city. The polychrome, in their approach, includes various components of natural ambient and architectural forms.

The Klee method is very similar to the one of Lenclos. However, in their method the last phase surpasses the boundaries of the pre-designing research and de facto corresponds to certain phases of urban planning on the master-plan level.

The work of Italian colourist Giovanni Brino [8] is well-known in domain of colour restoration and is based on restoration of the stone buildings as well as urban design restoration. One of the most important works by Brino is restoration of the city of Torino in Italy.

The experiment conducted by architecture theorist B. Frilling [9] brought a lot of the professional attention. He put the accent on the process of making the newly built objects picturesque. As an alternative, he suggested the giving of the artistic freedom to common people, but under architects' supervision in order to keep the general idea of the architectural project. This idea was realized in newly built objects in Berlin. This social-cultural experiment in Germany was perceived as a promising symptom of polychrome of massive new objects.

Nowadays, the natural / artificial ratio is significantly altered in favour of artificial. Humankind has already efficiently demonstrated its "supremacy" [10] over nature polluted with irreversible transformations: the gray concrete spaces flooded the nature suffocating its vivacious polychrome. It is impossible to make a stop in the process of finding new colouristic harmonies. This creative course must be further developed, but from the aspect of nature and architecture integrated - as the only acceptable form of their coexistence. This testifies of the need to keep natural values and achieve harmonious balance between natural and artificial. The colouristic harmonization of the urban environment is a task on a way higher level than the harmonization of the colour on surface and requires the spatial perception of colour. It is determined by the level of development of the culture of colour, social status and can be successfully solved in the process of architecturalurban design by using colouristic systems of the new generation as instruments of harmonization. The form, which represents the synthesis of natural ambient plasticity and architectural masses volume, partly determines the development of the urban colouristic ambient: the simple, regular form exacts balanced yet monotonous polychrome, while complex, chaotic form imposes uneven but various and picturesque polychrome.[11]

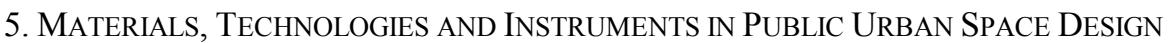

Construction material played the key role in design of coloured spatial structures of the city. Architectural polychrome significantly determines static or dynamic nature of the city ambiance. While historical settlements are characterized by colouristic inertness, new built areas easily accept the rapid pace of colouristic changes.

The contradiction between colouristic ambiance in expansion and existing industrial methods in building technology is noticeable. The continual development of colouristic ambiance imposes the need for dynamic architectural polychrome. This request grows in proportion to desire for urbanization, which constantly changes the relation between natural and artificial elements of the urban environment in favour of the latter ones. 
The colouristic dynamicity of the disappearing natural surroundings, obviously, has to be compensated with the artificial one. The request for dynamicity of architectural polychrome is predetermined by urbanization processes and, as such, is an objective phenomenon. [12]

The architectural polychrome can be achieved by creating more mobile technologies that would enable an easy change in colour and texture attributes of exterior constructions. By using more or less permanent colouristic finish, according to the programme of development of colouristic ambiance of public urban space, dynamic ambiance polychrome is created. Justified use of a specific finishing material or colour at specific city location would shorten the time spent on forming its colouristic ambiance and simultaneously reduce the expenses for numerous adaptations.

Nowadays, with new materials, building process loses its importance compared to the traditional building with wood and stone of yesterday, but it enables constructing imposing volumes of new buildings or whole cities. The important issue is improvement of colouristic materialization of buildings. Natural materials were used for construction, therefore their colour and texture reflected the structure of walls (log cabins, for example). Today, natural materials are mainly used for decorative purposes, and their colour does not correspond to the material used for the construction, making material's features and colour unrecognizable and illegible. Cladding, and paint alike, has its function in the sense of longevity of the building, but it also functions as "clothing". It is obvious that principles of multiple fencing of live organisms from their surroundings, certain independence from constructive skeleton and internal tissues and tight reciprocal relation to the organism itself and the surroundings, the change of its colour as a result of this reciprocity, represent the natural prototype for the surface of the architectural form.

It is possible that, through architectural understanding of materials, these principles have real materialization. There are, already, materials whose colour depends on temperature variations, like photo-chromatic glass, for example, which darkens in bright light. It is possible for walled surfaces of the building to have such a construction or cladding or dye that changes its colour and transparency according to the temperature or intensity and position of sunlight. Just like with living organisms, the colour can become thermoregulator in the process of thermal exchange or increase/reduce the function of construction. For example, in the conditions of the northernmost parts of the world, the self-illuminating fluorescent cladding can be used to enhance artificial city lighting during polar nights. For southern parts, the use of various sorts of vegetation on façades can be useful. The elements of architectural form covered in greenery cannot be distinguished from natural ones and therefore contribute to more appropriate interpolation of the architectural object within natural surroundings.

The abovementioned means of achieving architectural polychrome are in accordance with the idea of its mobility as they lay on natural-biotic basis.

\section{COMPOSING OF ARCHITECTURAL FORM}

It is interesting to analyze the range of the interactive link between polychrome and structural-morphological basis of architectural form. One of the two opposite poles represents the interaction based on "analogue composition", while the other represents the 
interaction according to "contradictory composition" that is a combination of shade and contrast.

"The models of chromatic solutions, which are derived from the principle of unity of the structure and colour combinations, are created according to structure and volume of the architectural form" [13]. It is difficult to oppose this thesis due to its absolute validity, although it does not reflect the wide range of interactive link of structure and colour but represents only one end of the analyzed scale. However, there is another end - the contradictory composition, contrast. Autonomy of polychrome from geometry of architectural form enables developing of volume and dynamics of that form and completing of various compositional tasks. The principle of polychrome contrast facilitates overcoming the static structural segregations of an object and upgrading its visual dynamics. In that case, the architecture takes over the live influence of natural surroundings' polychrome, social cultural processes, and culture of colour tendencies, i.e. it reacts operationally to the context change [14]

The colour of specific buildings usually stands somewhere in between the two opposites: polychrome contrast and shade, and geometrical shape of architectural structure. This is "combining by analogy" principle that can be applied to the individual building or the whole complex.

When composing the colours of an architectural composition, one should, primarily, select the multipurpose objects, clear chromatic characteristics and suitable formations of typical contrasts. While choosing the colour for immense group of buildings (regardless whether they are polyvalent or typical), exclusive attention should be focused on conditions that derive from specific spatial plan. Explicitly, changes of colour must emphasize compositional meaning of spatial structures within the buildings, rhythmical principles of their spatial correlation, dimensional comparison. [15]

\section{CONCLUSION}

A conclusion can be made that the change in physical pattern of public urban space by transforming into polychrome spaces following the function and cultural identity - can create valuable space suitable to various activities.

The colour is experienced as secondary architectural instrument that accentuates originally colourless compositional idea. Therefore, the combining by analogy principle presumes more tautological use of colour, denying colour as an important compositional mean in creation of artistic architectural form.

Colour drawings that represent contrast to relief surface can be seen on Spanish and Central Asian ceramics, Italian cathedrals' marble mosaics, and gothic Stained Glass. In seventeenth century Russia, whitewashed churches had decorative floral ornaments painted on. Sometimes, facades were decorated with painted "carved brilliant" pattern that evoked the impression of irrational architectural form. This principle came to great expansion in the beginning of the twentieth century.

The combining by contrast principle presumes more of a contradictory, energetic, transformable function of colour that opposes the geometry of the structure.

The directions for transformation of public urban space by the use of colour can be derived from the following principles: 
- Harmonizing of colour bearers in public urban space;

- Creating preconditions for achieving values: being understandable, emotionality, behaviour;

- Achieving chromatic harmony and systematization of chromatic multitude through cultural identity of environment.

This article was primarily dealing with establishing the colour-and-form, and formand-surroundings correlation. Further analysis has been done by introducing of polychrome elements in public urban space, pointing towards most suitable solutions containing values (being understandable, emotionality, behaviour). The given directions are valid for contemporary conditions.

\section{REFERENCES}

1. Марић И.: Традиционално градитељство Поморавља и савремена архитектура, ИАУС, 2006, p.41-42.

2. Vasiljevic Tomic D.: Natkriveni javni prostori grada, Zadužbina Andrejević, Beograd, 2003, p.45.

3. Васиљевић Томић Д.: Култура боје у граду, Архитектура и урбанизам 26, Београд, 2009, p.16.

4. Васиљевић Томић Д.: Феномен боје у дефинисању идентитета јавног градског простора, $\mathrm{PhD}$ thesis at University of Belgrade Faculty of Architecture, 2007, p.57.

5. Васиљевић Томић Д.: Феномен боје у дефинисану идентитета јавног градског простора, $\mathrm{PhD}$ thesis at University of Belgrade Faculty of Architecture, 2007, p.99.

6. Linton, H. Color in architecture, McGraw-Hill Edition-Europe, London, 2003, p.18.: "Lanklo publikuje knjigu svojih radova, 1982, Colors of France - Architecture and Landscape"

7. Ефимов, А.В.: Колористика города, Строуиздат, Москва, 1990, p.116.

8. Linton, H. Color in architecture, London :McGraw-Hill Edition-Europe, 2003, p.157.

9. Toy, M.: Architectural desidn: Color in architecture, Academy Group ltd., London, 1996, p.142.

10. Ефимов, А.В.: Колористика города, Строуиздат, Москва, 1990, р.67.

11. ibid. p.123.

12. Mueller, G.C.: Svjetlost $i$ vid, Mladost, Zagreb, 1972, p.123.

13. Ефимов, А.В.: Колористика города, Строуиздат, Москва, 1990, p.91.

14. ibid. p.123.

15. Mueller, G.C.: Svjetlost $i$ vid, Mladost, Zagreb, 1972, p.112.

\section{BOJA U GRADU: PRINCIPI PRIRODNO-KLIMATSKIH KARAKTERISTIKA \\ Dragana Vasiljević Tomić, Igor Marić}

Fenomen boje ispitan je kroz evoluciju boje i razvoj kolorističke kulture, koja značajno utiče na kolorističke prioritete ljudi i samu koloristiku grada. Termini funkcionalna boja i klima boje takođe su razmatrani kao jedni od najbitnijih odlika arhitektonske i zrbanističke prakse. Uloga javnog gradskog prostora u funkcionisanju grada definisana je osnovnim karakteristikama javnog gradskog prostora: kulturnim identitetom, prirodno-klimatskim karakteristikama $i$ fizičkom strukturom i njenom funkcijom. Kompleksnost kolorističkih odlika javnog gradskog prostora uslovljena je osnovnim karakteristikama: kolorističkim prioritetima, harmonijom bojenih prostornih struktura i materijala $u$ projektovanju polihromnih ambijenata u gradu. Formirani su novi prncipi na kojima je izgrađen transformisani model javnog gradskog prostora kao polihromnog ambijenta.

Key words: boja, polihromija, kultura, prirodno-klimatske karakteristike, prostor. 